\title{
Fragmentation of Headquarter Services and FDI
}

\author{
Ronald B. Davies*
}

September 2003

\begin{abstract}
I develop a simple model in which production of skill-intensive headquarter services are fragmented across borders in order to take advantage of complementarities between types of skilled labor. This setting indicates that FDI tends to come from and go to skill-abundant countries. It also yields an ambiguous effect of FDI on domestic relative wages. If the complementarities between skilled labor types are large enough, then increased FDI increases the wages of both skilled and unskilled labor in the home economy. Thus, this model predicts investment patterns comparable to the horizontal model but requires neither trade barriers nor reductions in home wages.
\end{abstract}

JEL Classification: F16, F23

Key Words: Headquarter Services, Fragmentation, Foreign Direct Investment

* 435 PLC Building, 1285 University of Oregon, Eugene, OR, 97405; Phone: (541) 346-4671; Fax: (541)

346-1243; E-mail: rdavies@uoregon.edu. All errors are entirely my responsibility. 


\section{Introduction}

Over the past twenty years, there have arisen two competing theories of the multinational enterprise (MNE). In the horizontal model (Markusen, 1984), foreign direct investment (FDI) arises because of firm-level scale economies combined with barriers to trade. In the vertical model (Helpman, 1984), FDI occurs when production is fragmented across borders because of international factor price differences. Recently, a body of empirical work has emerged that finds that most FDI takes place between similar countries (see, for example, Markusen and Maskus (1999) or Blonigen, Davies, and Head (2003)). Since similar countries are likely to have similar factor prices, these findings have been interpreted as support for the horizontal model. An alternative reading of the data, however, simply says that most FDI flows from and goes to skill-rich countries. In this paper, I offer a new model of FDI in which investment is driven by complementarities between the types of skilled labor available in different countries. This leads the MNE to fragment the headquarter part of its production across borders. This fragmentation implies that FDI is most prevalent between countries with large pools of skilled labor, a result that matches the data. In addition, my model yields two major changes relative to the standard models of FDI. First, MNEs arise even with identical countries, no scale economies, and no trade costs. Second, depending on the size of the complementarities, an increase in FDI can lead to an increase in the wages of both skilled and unskilled domestic labor, a result which may alleviate some of the concerns over outbound FDI.

In the next section, I discuss the role of fragmentation in the existing FDI literature. I also include a summary of the relevant empirical evidence. There, I note 
some of the issues that the most common interpretation of the data cannot explain. In Section 3, I present my model and discuss its implications for investment patterns and wages. Section 4 concludes with some potential implications of fragmented headquarter services for government policy.

\section{Fragmentation and FDI}

Fragmentation plays an important role in both the horizontal and vertical models of FDI. In both, production of the MNE's good is a two stage process. In the first stage, the MNE produces headquarter services. These are intended to represent research and development, management, advertising, and the like. As summarized by Caves (1993), in the earliest work on FDI these services took on a prominent role because they gave the firm a reason to internalize its overseas activities, thereby creating the distinction between FDI and simple outsourcing. These headquarter services are then combined with other factors in a production stage. Although early models such as Helpman (1984) and Markusen (1984) used the traditional capital/labor dichotomy, more recently the focus has shifted to the interplay between skilled and unskilled labor (see for example Venables, 1999, or Markusen and Venables, 2000). In this work, headquarter services are generally assumed to be skill-intensive relative to production of the MNE's good. MNE production is in turn skill-intensive relative to the production of other goods in the economy. Regardless of factors used in each stage, it is generally thought that these stages can be fragmented and carried out in different countries with the MNE's home or parent country defined as the location in which it does its headquarter activities. The way 
in which headquarter services are used in the production stage is critical when differentiating between the vertical and horizontal models.

In the horizontal model, headquarter services are a joint input that can be used in multiple production facilities without reducing their marginal productivity. Thus, a single firm with production in two countries has a cost advantage over two separate, national firms because it need not duplicate production of the headquarter services. This yields firm-level scale economies. When the joint input nature of headquarter services is combined with trade barriers (either natural or artificial), the firm has an incentive to produce in both countries in order to serve each market locally. This implies that there is FDI. Note that although there is a vertical relationship with the headquarter services acting as an intermediate input, that the production of the same final good in multiple countries leads to the "horizontal" designation. On implication of this motivation for MNEs is that horizontal FDI is a substitute for trade because FDI replaces exports. Note the importance of trade barriers to this result, because under constant returns to scale, horizontal FDI is unnecessary unless there is a cost savings to producing in each market. Furthermore, if there are plant-level fixed costs, as assumed by Markusen and Venables (1998) and others, then trade barriers become a necessary condition for horizontal FDI.

In the vertical model, FDI results from the forces that are typically associated with fragmentation, namely, factor price differences. In Helpman's (1984) original model, FDI occurs when relative factor endowments lie outside the factor price equalization set, i.e. trade alone cannot equilibrate factor prices. Thus, FDI flows from the skill-abundant home country to the skill-deficient host. ${ }^{1}$ Recent models in this vein include Feenstra and

\footnotetext{
${ }^{1}$ Note that in order for firms to choose overseas investment instead of outsourcing, there must also be an internalization motivation as described by Caves (1993).
} 
Hanson (1996a, 1997) and Eckel (2003). ${ }^{2}$ Vertical FDI has similar motivations as the fragmentation of trade through outsourcing since countries specialize in stages of the production process according to their comparative advantage. It is important to note, however, that this outsourcing does not count legally as FDI and therefore is not counted as such in the data. Thus, in the vertical MNE, the firm creates headquarter services in one country and produces in the other. One result of this is that FDI is a compliment to trade because increased FDI means more overseas production, some of which is shipped back home.

Recently, there has been a push to integrate the horizontal and vertical motivations into a single, unified framework. Examples of this work include Markusen, Venables, Konan, and Zhang (1996), Venables (1999), and Markusen (2002). One of the key findings from this exercise is that the prevalence of the two types of FDI depends on the parameters of the model. In particular, horizontal FDI is more common when relative endowments are equal whereas vertical FDI arises when endowments differ. Since the horizontal firm must produce in both countries, as endowments differ and factor prices diverge, the MNE has an incentive to switch either to a vertical or national firm structure in which it eliminates fragmentation. Vertical FDI, however, exists precisely because very different endowments create factor price differences that cannot be eliminated by the trade in goods. This difference in these two models has been exploited by empirical researchers including Markusen and Maskus (1999) and Blonigen, Davies, and Head (2003), who find that most FDI takes place between countries with similar endowments. They interpret this finding as evidence that most FDI fits the horizontal model. In fact,

\footnotetext{
${ }^{2}$ While I do not discuss the literature on fragmentation of trade, I refer the interested reader to Dixit and Grossman (1982) or Jones and Kierzkowski (1990) as solid gateways into the topic.
} 
evidence of vertical FDI is relatively hard to come by, although Davies (2002) and Braconier, Norbäck, and Urban (2002) do find some evidence suggestive of vertical FDI.

While these results might seem to put the issue to rest, there remain some difficulties in reconciling the evidence with the theory. First, although horizontal FDI is intended to replace trade in goods, there remains a significant amount of trade not only between developed countries but within the MNEs they share. According to the numbers presented by Markusen (2002) and reproduced in Table 1, intra-firm trade for U.S. affiliates in developed countries accounts for approximately ten percent of affiliate sales. For foreign affiliates in the U.S. from developed countries, such trade accounts for approximately one quarter of affiliate sales. This amount of intra-firm trade suggests that even between countries with similar costs, there is a good deal of fragmentation occurring.

Second, one of the results common to both horizontal and vertical FDI models is that FDI can have detrimental effects on the wages paid to domestic factors, especially those used in the production stage. In the vertical model, this effect is obvious since the point of FDI is to relocate production to where the factors used intensively in production (such as unskilled labor) are cheapest. In Helpman's (1984) original version, this can go so far as to equalize factor prices, with all of the distributional effects that factor price equalization entails. ${ }^{3}$ In horizontal models, because FDI replaces domestic production a comparable effect can arise. Thus, the expectation is that increases in outbound FDI should reduce the wages of unskilled workers at home. Nevertheless, this effect is notoriously difficult to find. Surveys by the OECD (1995) and Slaughter and Swagel

\footnotetext{
${ }^{3}$ As noted by Helpman (1984) and Venables (1999) for very unequal relative endowments, factor prices may not equalize even with trade and FDI,.
} 
(1997) report that on the whole, outbound FDI appears to have little impact on wage differentials. More recent evidence from Slaughter (2000) finds similar results. ${ }^{4}$ There do exist potential explanations for this non-effect in the literature. Braconier and Ekholm (2000) and Eckel (2003) show that due to cost savings created by relocating production to low cost locations, there is an efficiency-enhancing effect that increases domestic wages. When this is paired with the production shift, the net effect on wages is ambiguous. However, both consider vertical FDI which the data suggests is fairly rare. In the horizontal model, it is also possible to find an increase in domestic wages with FDI. To obtain this result, consider a world in which there is no FDI but with two national firms. When these are replaced by a single MNE, this creates a cost savings by eliminating duplication of headquarter services. Comparable to Braconier and Ekholm (2000) or Eckel (2003), if this savings is large enough, then the creation of a MNE can increase production at home and increase the wages of production workers. However, this result comes about from a change in market structure, thus an expansion of an existing MNE would still be expected to decrease domestic production wages. Thus, the existing models do not provide fully convincing explanations for the missing wage effect.

Third, if FDI is intended to serve a local market as the horizontal model suggests, then one would expect host country trade barriers to be positively related to FDI. While the empirical evidence on FDI generally finds such a relationship, there remain surprises. For example, one would expect the creation of trade agreements such as NAFTA to divert FDI by non-member countries from the high-cost U.S. to low-cost Mexico. Nevertheless, although Mexico did see an increase in inbound FDI after NAFTA, as

\footnotetext{
${ }^{4}$ Feenstra and Hanson (1996c), and Sachs and Shatz (1994) do, however, find a negative effect of outsourcing on the relative wage of unskilled workers, again highlighting the differences between FDI and outsourcing.
} 
Waldkirch (2003) shows, this was the result of increased investment from the U.S. and Canada, not from non-NAFTA countries. Thus, despite the ability to shift production to the low-cost Mexico yet still serve the lucrative U.S. market cheaply, European firms did not react as expected.

Because of these unanswered questions, there is a need for additional models of FDI that rely neither on factor price differences no trade barriers. Additionally, these models should include forces by which increased FDI can have positive effects on domestic unskilled wages. To that end, I offer a model in which, rather than separating headquarter activities from production as in the traditional fragmentation models, I allow MNEs to fragment the creation of their headquarter services across borders. One reason that a firm would do so is that skilled workers from different backgrounds provide different viewpoints and ideas that compliment one another. Thus, even though workers may be employed in similar occupations or have the same amount of education common proxies for skill - they may complement one another in a way that workers from the same country do not. Since labor is not especially mobile across borders, the immobility of these different skilled workers gives firms a reason to locate an office in a different country. ${ }^{5}$ Since this does not rely on factor price differences, FDI occurs between identical countries even without trade costs. Furthermore, this suggests that FDI is most likely to come from and go to countries with large amounts of skilled workers.

As Markusen (2002) reports, the skill-abundant developed countries are the homes of approximately 95 percent of FDI and are hosts for approximately 75 percent of

\footnotetext{
${ }^{5}$ As detailed in Graham and Krugman (1995), an office or other place of management that lasts more than twelve months satisfies the definition of a permanent establishment, a condition necessary for economic activity to be classified as FDI. Thus, the legal definition and the data include more activity than simply actual production.
} 
FDI. Thus, the data reflects that most FDI does indeed come from and go to skillabundant countries. However, when studies such as Markusen and Maskus (1999) find a negative effect of skill differences on FDI, it may be that they are simply capturing the impact of small supplies of skilled labor in one country or the other. As a test of this possibility, I offer the regression results in Table 2. These results come from OLS estimation of the FDI empirical specification established by Carr, Markusen, and Maskus (2001). I use their graciously-provided data, which is the same data used by Markusen and Maskus (1999) and Blonigen, Davies, and Head (2003). In the interest of space, I refer the interested reader to Carr, Markusen, and Maskus for a detailed description of the variables and the data. For my current devices, it suffices to note that the dependent variable is sales by affiliates of U.S. MNEs and foreign-owned affiliates in the U.S. for the period 1986 to 1994. Also, it is worth noting that the measure of skilled labor availability is the percentage of workers employed in either the $0 / 1$ (professional, technical, and kindred workers) or 2 (administrative workers) job categories in the parent minus that in the host. ${ }^{6}$ There are two differences in my specification relative to that of Carr, Markusen, and Maskus. First, as per the issues raised by Blonigen, Davies, and Head, I separately estimate results for skill-abundant (Columns 1 and 2 of Table 2) and skill-deficient parents (Columns 3 and 4). ${ }^{7}$ Second, in Columns 1 and 3 I use the skill difference between the home and host countries as in the original empirical specification. In Columns 2 and 4, I instead use the endowment of skilled labor in the home and host countries separately.

\footnotetext{
${ }^{6}$ This data comes from the International Labor Organization.

${ }^{7}$ Note that using this measure of skill, the U.S. is almost always the skill-abundant country.
} 
Focusing attention on the skill variable, in columns 1 and 3, I find that FDI activity is decreasing in skill differences. This is the result found by Markusen and Maskus (1999) and Blonigen, Davies, and Head (2003) who interpreted it as evidence of horizontal FDI. ${ }^{8}$ In columns 2 and 4, however, I find that FDI is increasing in the amount of skill available of both countries. Furthermore, the fit of the specification improves considerably, raising the $\mathrm{R}^{2}$ for positive skill differences from .55 to .71 and for negative skill differences from .47 to .57 . Thus, this suggests that the difference variable is capturing low levels of skill in either the home or host and that it is not necessarily differences that matter so much as the amount of skill available in each country.

A second implication of this fragmented headquarters model of FDI is that because overseas skilled labor can be a complement for both skilled and unskilled domestic FDI, increases in FDI result in wage increases for both types of domestic labor. Therefore increases in FDI need not lower domestic wages and can in fact increase the relative wage of unskilled workers.

With these goals for my model of FDI in mind, I now lay it out in detail.

\section{A Simple Model of Fragmented Headquarter Services}

In this section I present a basic model with headquarter fragmentation. This model does not include many issues commonly found in models of FDI or fragmentation such as imperfect competition or increasing returns to scale. While these matters are clearly important for developing an exhaustive model of FDI, I leave them out of the current presentation because even in this simple framework I find ambiguity in the interplay

\footnotetext{
${ }^{8}$ In the negative column, recall that the positive coefficient means that as the skill difference gets less negative, i.e. goes towards zero, that FDI goes up.
} 
between domestic and foreign inputs. Because this ambiguity would persist in a more complex model making any conclusions there conditional at best, I have chosen to focus the current discussion to gain a better perspective on the forces that give rise to this conflict in isolation.

Consider a world with three goods that are produced under perfect competition and sold at constant prices on the world market, indicating that both the home and host countries are small. ${ }^{9}$ There are no trade barriers. Good $\mathrm{Y}$ is produced using skilled labor and sector specific capital according to a constant returns to scale technology $Y\left(s, K_{Y}\right)$ where the function is scaled such that the price of $\mathrm{Y}$ is one. A similar sector exists in the host market, where its output of $\mathrm{Y}$ is given by $Y^{*}\left(s^{*}, K_{Y}^{*}\right)$. Similarly, good $\mathrm{Z}$ is produced using unskilled labor and sector-specific capital according to the constant returns to scale technology $Z\left(u, K_{z}\right)$. Again, this function is scaled such that the price of $Z$ is one. ${ }^{10}$

Finally, a good $\mathrm{X}$ is produced using skilled and unskilled labor and sold at a constant price on the world market. This production takes place through a two-stage process. First, skilled labor is used to produce headquarter services. This labor can come either from the home country (S) or from the host country $\left(\mathrm{S}^{*}\right)$. I impose two assumptions on this process. First, it is not necessary to use skilled labor from both countries, that is, all headquarter services can be produced in one country. Thus, although firms can become multinationals, this is not necessary for $\mathrm{X}$ to be produced. Second, there exist complementarities between domestic and foreign skilled labor. These complementarities are intended to represent the interaction of the differing ideas, skills, and backgrounds of

\footnotetext{
${ }^{9}$ Again, these assumptions allow me to narrow the possible reasons for the emergence of MNEs.

${ }^{10}$ As noted below, I assume that all of the MNE's unskilled labor is hired in the home country, allowing me to ignore the effect of the host's $Z$ sector.
} 
skilled workers from the two countries. Combining these assumptions means that the production of headquarter services is:

$$
H=S+H\left(S, S^{*}\right)+S^{*}
$$

As noted above, in order to remove increasing returns to scale arguments for FDI, I assume that the function $H\left(S, S^{*}\right)$ is homogeneous of degree one. These headquarter services are then combined with unskilled labor to produce the final good. This is represented by the constant returns to scale production function:

$$
X=X(H, U)
$$

which is scaled so that the price of $\mathrm{X}$ is equal to one. Since the $\mathrm{X}$ production function exhibits constant returns, in the absence of factor price differences and trade costs, there is no reason for the firm to maintain separate production facilities. Thus, in order to remove both horizontal and vertical motivations for fragmenting the production process, I assume that all unskilled labor is hired from a single source and that the firm sells its product on the world market from this single location. Note that this allows me to use $\mathrm{S}^{*}$ as my measure of FDI.

The firm takes the prices of its three inputs as given. The price for domestic skilled labor is w, the price for foreign skilled labor is $\mathrm{w}^{*}$, and the price of unskilled labor is $r$. This yields a profit function for the MNE of:

$$
\Pi\left(S, S^{*}, U\right)=X\left(S+H\left(S, S^{*}\right)+S^{*}, U\right)-w S-w^{*} S^{*}-r U
$$

Finally home endowments of skilled and unskilled labor are $\bar{S}$ and $\bar{U}$ and the foreign endowment of skilled labor is $\bar{S}^{*}$. Using perfect competition in factor markets, the first order conditions of (3) yield three equilibrium conditions:

$$
X_{1}\left(S+H\left(S, S^{*}\right)+S^{*}, U\right) \cdot\left(1+H_{1}(S, U)\right)=Y_{1}\left(\bar{S}-S, K_{y}\right)
$$




$$
X_{1}\left(S+H\left(S, S^{*}\right)+S^{*}, U\right) \cdot\left(1+H_{2}(S, U)\right)=Y_{1}^{*}\left(\bar{S}^{*}-S^{*}, K_{y}^{*}\right)
$$

and

$$
X_{2}\left(S+H\left(S, S^{*}\right)+S^{*}, U\right)=Z_{1}\left(\bar{U}-U, K_{Z}\right)
$$

where number subscripts denote derivatives with respect to the appropriate argument. These three conditions simply imply that the marginal benefit of each factor is equated across sectors. Note that I am assuming that both domestic and foreign skilled labor are employed in equilibrium, a condition which is guaranteed if the function $\mathrm{H}$ satisfies the Inada conditions.

From these three equilibrium conditions, I can derive the following results.

Proposition 1: The MNE's use of home skilled labor, host skilled labor, and unskilled labor in the multinational sector are all increasing in their own supplies.

Proof: For notational convenience, I suppress the arguments of functions for the rest of the paper. It is also useful to define:

$$
\begin{aligned}
\Phi \equiv & X_{11} Z_{11}\left(\left(1+H_{1}\right)^{2}\left(X_{1} H_{22}+Y_{11}^{*}\right)+\left(1+H_{2}\right)^{2}\left(X_{1} H_{11}+Y_{11}\right)\right)+X_{1} H_{11} Y_{11}^{*}\left(X_{22}+Z_{11}\right) \\
& +X_{1} H_{22} Y_{11}\left(X_{22}+Z_{11}\right)+X_{22} Y_{11} Y_{11}^{*}+Y_{11} Y_{11}^{*} Z_{11}-2 X_{1} X_{11}\left(1+H_{1}\right)\left(1+H_{2}\right) H_{12} Z_{11}
\end{aligned}
$$

which is negative. Differentiation of (4) through (6) yields the following comparative statics:

$$
\begin{aligned}
& \frac{d S}{d \bar{S}}=\frac{Y_{11}}{\Phi}\left(X_{11}\left(1+H_{2}\right)^{2} Z_{11}+\left(X_{1} H_{22}+Y_{11}^{*}\right)\left(X_{22}+Z_{11}\right)\right)>0 \\
& \frac{d S^{*}}{d \bar{S}^{*}}=\frac{Y_{11}^{*}}{\Phi}\left(X_{11}\left(1+H_{1}\right)^{2} Z_{11}+\left(X_{1} H_{11}+Y_{11}\right)\left(X_{22}+Z_{11}\right)\right)>0
\end{aligned}
$$

and

$$
\begin{aligned}
\frac{d U}{d \bar{U}}= & \frac{Z_{11}}{\Phi}\left(X_{1} X_{11}\left(H_{22}\left(1+H_{1}\right)^{2}+H_{11}\left(1+H_{2}\right)^{2}-2\left(1+H_{1}\right)\left(1+H_{2}\right) H_{12}\right)\right. \\
& \left.+Y_{11}\left(X_{11}\left(1+H_{2}\right)^{2}+X_{1} H_{22}\right)+Y_{11}^{*}\left(X_{11}\left(1+H_{1}\right)^{2}+X_{1} H_{11}\right)+Y_{11} Y_{11}^{*}\right)>0
\end{aligned}
$$


The intuition for this result is straightforward; with an increase in the supply of these non-specific factors, given the fixed amount of sector-specific capital in the $\mathrm{Y}$ and $\mathrm{Z}$ sectors, their factor prices fall, leading to greater use of them in the production of $\mathrm{X}$. Although I leave out the exact derivation, a rise in $\mathrm{K}_{\mathrm{y}}$ reduces $\mathrm{S}$, a rise in $\mathrm{K}_{\mathrm{y}}{ }^{*}$ reduces $\mathrm{S}^{*}$, and a rise in $\mathrm{K}_{\mathrm{Z}}$ reduces $\mathrm{U}$ for comparable reasons. The interaction between skilled labor, regardless of its nationality, and unskilled labor is also straightforward.

Proposition 2: An increase in the supply of skilled labor in either country increases the amount of unskilled labor used in the production of the multinational good. Also, an increase in the supply of unskilled labor increases the use of skilled labor from both countries in the multinational sector.

Proof: Again, differentiating the equilibrium conditions, I find that:

$$
\begin{aligned}
& \frac{d U}{d \bar{S}}=\frac{Y_{11} X_{12}}{\Phi}\left(X_{1} H_{12}\left(1+H_{2}\right)-\left(1+H_{1}\right)\left(X_{1} H_{22}+Y_{11}^{*}\right)>0\right. \\
& \frac{d U}{d \bar{S}^{*}}=\frac{Y_{11}^{*} X_{12}}{\Phi}\left(X_{1} H_{12}\left(1+H_{1}\right)-\left(1+H_{2}\right)\left(X_{1} H_{11}+Y_{11}\right)>0\right. \\
& \frac{d S}{d \bar{U}}=\frac{Z_{11} X_{12}}{\Phi}\left(X_{1} H_{12}\left(1+H_{2}\right)-\left(1+H_{1}\right)\left(X_{1} H_{22}+Y_{11}^{*}\right)>0\right. \\
& \frac{d S^{*}}{d \bar{U}}=\frac{Z_{11} X_{12}}{\Phi}\left(X_{1} H_{12}\left(1+H_{1}\right)-\left(1+H_{2}\right)\left(X_{1} H_{11}+Y_{11}\right)>0\right.
\end{aligned}
$$

Q.E.D.

As the supply of skilled labor in either country rises, more is employed in X production, raising the productivity and the use of unskilled labor in that sector. Similarly, as the supply of unskilled labor rises, increasing the use of unskilled labor in X production, this increases the productivity and use of skilled labor from both countries in that sector. The 
interaction between the supply of skilled labor in one country and the use of skilled labor from the other is less clear, however. Again using my equilibrium conditions, I find that:

$$
\frac{d S^{*}}{d \bar{S}}=\frac{Y_{11}}{\Phi}\left(-X_{1} H_{12}\left(X_{22}+Z_{11}\right)-X_{11}\left(1+H_{1}\right)\left(1+H_{2}\right) Z_{11}\right)
$$

and

$$
\frac{d S}{d \bar{S}^{*}}=\frac{Y_{11}^{*}}{\Phi}\left(-X_{1} H_{12}\left(X_{22}+Z_{11}\right)-X_{11}\left(1+H_{1}\right)\left(1+H_{2}\right) Z_{11}\right)
$$

both of which are ambiguous. The multiplicative term in each equation is positive. The first term in the parentheses is positive and represents the complementarities in production between the two types of skilled labor. The second term, however, is negative and represents the substitutability between labor types. In general, it is impossible to say which of these is larger. In the standard models without complementarities, the first term is zero, resulting in pure substitutability between skilled labor types. In that case, starting from a position of identical countries, a rise in domestic skill reduces FDI. Without complementarities, although a rise in foreign skill would increase FDI in my simple model, it would reduce domestic use of skilled labor, thus moving the firm from a horizontal-looking MNE towards a vertical-style MNE. This result is summarized in the following proposition.

Proposition 3: If home and host skilled labor are sufficiently complimentary, then a rise in skilled labor supply in either country increases FDI. If not, then a rise in home's endowment of skilled labor reduces FDI whereas a rise in host's skilled labor endowment increases FDI.

Thus, when it is highly beneficial to mix the skilled labor types when producing headquarter services, FDI will tend to come from and go to skill-abundant countries, a pattern that matches the data. At this point, it is worth giving some thought to when 
complementarities between labor types are likely to be large. At the national level, one would expect that factors such as language barriers, cultural differences, and distance make it difficult for interaction to take place. Jolly (2002) and Guellec and van Pottelsberghe de la Potterie (2001) study international patent citations and find that international collaboration is indeed hindered by these factors. Comparable patterns are found in empirical studies of FDI. For example, Brainard (1997) finds that a common language and a shorter distance increase the FDI activity between the U.S. and another country. The regressions in Table 2 also find a negative effect of distance.

In addition to factors affecting the ease of communication, there is a body of literature that posits that spillovers such as technology transfers are embodied in workers and that spillovers occur through labor market churning. Thus, the complementarities between types of skilled labor can be interpreted as arising from the spillovers created by other firms active in the host country. Jaffe and Trajtenberg (1999) and Keller (2002) find that spillovers from technological diffusion are fairly local which is consistent with this idea when labor is relatively immobile. In such a case, firms would have an incentive to locate near other firms to gain access to their former skilled workers even if that labor is not the cheapest available. At the industry level, this would give rise to agglomeration patterns, evidence of which is found by Head, Reis, and Swenson (1995) and Guimaraes, Figueiredo, and Woodword (2000). Furthermore, one might expect that the importance of spillovers varies across industries and are particularly important for skill-intensive industries. Since the developed countries, who host the majority of FDI, are also the countries that specialize in skill-intensive products, this would give another explanation for the cross-country variation in inbound FDI stocks. Furthermore, if investment into a 
country such as the U.S. is an attempt to gain access to the spillovers embodied in its skilled workers, then a reduction in trade barriers from NAFTA would not be expected to cause non-members to move their FDI south.

The result that increases in FDI can increase employment of both skilled and unskilled labor at home also has interesting implications for wages. Given the above results, it is clear that when the complementarities between skilled labor types are large, then an increase in FDI would increase the wages of both domestic skilled and unskilled labor. If the percentage increases are comparable for skilled and unskilled labor, then this implies that an increase in FDI would not change the relative wage of production workers. This does not happen in the standard models of FDI since increased outbound investment means less production of the final good at home. This result can help to explain why Slaughter (2000) does not find an effect from outbound FDI on wages but outsourcing, which is more akin to vertical FDI, does appear to have negative effects on wages. Note that increases in outbound FDI do increase the relative wage of skilled workers in the host. This implies that inbound FDI increases the relative wage of skilled workers, a result consistent with the empirical findings of Feenstra and Hanson (1997).

\section{Conclusion}

The goal of this paper was to present a simple model of FDI in which headquarter services are fragmented across borders in order to take advantage of complementarities between different types of labor. This yields two useful results. First, FDI of this type is likely to be most prevalent when the home and the host are both well-endowed with skilled labor. This fits the observed patterns of investment in which most investment 
flows between skilled countries. Second, with fragmented headquarter services, increases in FDI can increase the wages of all factors used in the multinational industry. This can help to explain why we do not observe the detrimental wage effects that standard horizontal or vertical models of FDI anticipate.

Despite my reluctance to call my model vertical in the traditional sense, it clearly has a strong vertical flavor to it. In fact, it is possible to present it somewhat differently by describing it as a model with three distinct types of labor, two of which of available at home and one of which is available in the host. Since the price of home skilled labor in the host and host skilled labor in home are both infinity, one can view fragmented headquarter FDI as a type of vertical FDI. I did not choose this route because my approach was influenced heavily by the data in which distinctions between types of skilled labor are note made (although as my regressions suggest, perhaps they should be). Alternatively, since headquarter services are produced in each country, it is also possible to cast my model as a variant of horizontal FDI since the same activity is performed in multiple countries. I have avoided choosing either of these terms to describe my model since it grew out of a reaction to the existing models and is intended to add to them, not replace them. Nevertheless, by rethinking the role of fragmentation in FDI, it is possible to find something quite akin vertical investment even between similar countries. In a world in which production of services is becoming ever more fragmented from production, I believe that recognizing that even the production of services can be fragmented across borders is useful when analyzing both trade and FDI.

Finally, my model has some interesting implications for government policy. Since the impact of endowments on FDI and of FDI on wages depend crucially on the degrees 
to which skilled labor types complement one another, this interaction itself can be the target of policy. First, although it is generally recognized that creating a skilled workforce can attract FDI overall, it may be possible to target investment from particular countries by working to increase country-specific complementarities. For example, in order to attract Japanese FDI, it may be worthwhile to concentrate on teaching local workers basic Japanese and familiarizing them with Japanese culture. Second, if spillovers are embodied in local workers, then increasing labor use by the first MNE in an area may increase agglomeration effects. This gives an additional rationale for the performance requirements many hosts impose on incoming MNEs that specify hiring levels, particularly those in high-skill occupations. ${ }^{11}$

${ }^{11}$ Graham (2000) provides an overview of common performance requirements. 


\section{References}

Blonigen, Bruce A., Ronald B. Davies and Keith Head (2003), "Estimating the Knowledge-Capital Model of the Multinational Enterprise: Comment," American Economic Review, 93(3): pp. 980-994.

Braconier, Henrick and Karolina Ekholm (2000), "Swedish Multinationals and Competiton from High and Low-Wage Locations, " Review of International Economics, 8, pp. $448-61$.

Braconier, Henrik, Pehr-Johan Norb@k, and Dieter Urban (2002), "Vertical FDI Revisited," Mimeo.

Brainard, S. Lael (1997), "An empirical assessment of the proximity-concentration tradeoff between multinational sales and trade," American Economic Review, 87:4, pp. 520544.

Carr, David L.; Markusen, James R. and Maskus, Keith E. (2001), "Estimating the Knowledge-Capital Model of the Multinational Enterprise." American Economic Review, 91(3), pp. 693-708.

Caves, Richard E. (1993), Multinational Enterprise and Economic Analysis, Second Edition, Cambridge Surveys of Economic Literature, Cambridge Press, New York, New York.

Davies, Ronald B. (2002), “Hunting High and Low for Vertical FDI,” Mimeo.

Dixit, Avinash and Gene Grossman (1982), "Trade and protection with multistage production," Review of Economic Studies, 49, pp. 583-594.

Eckel, Carsten (2003), "Fragmentation, Efficiency-Seeking FDI, and Employment," Review of International Economics, 11(2), pp. 317-331.

Feenstra, Robert and Gordon Hanson, (1996a), Foreign investment, outsourcing, and relative wages," in Feenstr, R., Grossman, G., Irwin, D. (eds.) Political Economy of Trade Policy: Essays in Honor of Jagdish Bhagwati, Cambridge: MIT Press, pp. 89-127.

Feenstra, Robert and Gordon Hanson, (1996b), "Globalization, Outsourcing, and Wage Inequality, American Economic Review, pp. 240-245.

Feenstra, Robert and Gordon Hanson, (1997), "Foreign Direct Investment and Relative Wages: Evidence from Mexican Maquiladoras," Journal of International Economics, 42, pp. 371-393.

Glass, Amy J. and Kamal Saggi, (1999), "FDI Policies under Shared Factor Markets," Journal of International Economics, 49, pp. 309-332. 
Graham, Edward M. (2000), Fighting the Wrong Enemy: Antiglobal Activists and Multinational Enterprises, Institute for International Economics, Washington D.C..

Graham, Edward and Paul Krugman (1995), Foreign Direct Investment in the United States, Third Edition, Institute for International Economics, Washington, D.C..

Guimaras, Paulo, Octavio Figueiredo, and Douglas Woodward (2000), "Agglomeration and the Location of Foreign Direct Investment in Portugal," Journal of Urban Economics, 47(1), pp. 115-135.

Guellec, Dominique and Bruno van Pottelsberghe de la Potterie (2001), "The Internationalisation of Technology Analysed with Patent Data," Research Policy, 30(8), pp. 1253-1266.

Head, Keith, John Ries, and Deborah Swenson (1995), “Agglomeration benefits and location choice: evidence from Japanese manufacturing investments in the United States," Journal of International Economics, 38 (3-4), 223-247.

Helpman, Elhanan (1984), "A Simple Theory of International Trade with Multinational Corporations." Journal of Political Economy, 94(3), pp. 451-71.

Jaffe, Adam and Manuel Trajtenberg (1999), "International Knowledge Flows: Evidence from Patent Citations," Economics of Innovation and New Technology, 8(1-2), pp. 105136.

Jolly, Dominique (2002), "Sharing Knowledge and Decision Power in Sino-Foreign Joint Ventures," Asia Pacific Business Review, 9(2), pp. 81-100.

Jones, Ronald W. and Henryk Kierzkowski (1986), "Neighborhood Production Structures, with an Application to the Theory of International Trade," Oxford Economic Papers, 38, pp. 59-76.

Keller, Wolfgang (2002), “Geographic Localization of International Technology Diffusion," American Economic Review, 92(1), pp. 120-142.

Markusen, James R. (1984), "Multinationals, Multi-plant Economies, and the Gains from Trade.” Journal of International Economics, 16(3/4), pp. 205-26.

Markusen, James R. (2002), Multinational Firms and the Theory of International Trade, Cambridge: The MIT Press.

Markusen, James R. and Maskus, Keith E. (1999), "Discriminating Among Alternative Theories of the Multinational Enterprise," National Bureau of Economic Research (Cambridge, MA) Working Paper No. 7164. 
Markusen, James R. and Venables, Anthony J. (1998), "Multinational Firms and the New Trade Theory.” Journal of International Economics, 46(2), pp. 183-203.

Markusen, James R. and Venables, Anthony J. (2000), “The Theory of Endowment, Intra-Industry and Multinational Trade." Journal of International Economics, 52(2), pp. 209-34.

Markusen, James R.; Venables, Anthony J., Eby-Konan, Denise and Zhang, Kevin Honglin (1996), “A Unified Treatment of Horizontal Direct Investment, Vertical Direct Investment, and the Pattern of Trade in Goods and Services," National Bureau of Economic Research (Cambridge, MA), Working Paper No. 5696.

Organization for Economic Cooperation and Development (1995), "Review of Recent Case Studies of Employment Effects of FDI," in OECD (eds.), Foreign Direct Investment, Trade and Employment, Paris: OECD, pp. 140-145.

Sachs, Jeffery and Howard Shatz (1994), "Trade and Jobs in U.S. Manufacturing," Brookings Papers on Economic Activity, 1, pp. 1-69.

Slaughter, Matthew J. (2000), "Production transfer within multinational Enterprises and American Wages," Journal of International Economics, 50(2), pp. 449-472.

Slaughter, Matthew J. and Phillip Swagel (1997), "The Effect of Globalization on Wages in the Advanced Economies," IMF Working Paper WP/97/43.

Venables, Anthony J. (1999), "Fragmentation and Multinational Production, European Economic Review, 43(4-6), pp. 935-945.

Waldkirch, Andreas (2003), "The new regionalism and foreign direct investment: the case of Mexico," The Journal of International Trade and Economic Development, 12(2), pp. 
Table 1: Parent-Affiliate Trade as a Percentage of Total Affiliate Sales (1997)

\begin{tabular}{lcccc} 
& \multicolumn{2}{c}{ U.S. Outbound FDI } & \multicolumn{2}{c}{ U.S. Inbound FDI } \\
& $\begin{array}{c}\text { Affiliate } \\
\text { Imports }\end{array}$ & $\begin{array}{c}\text { Affiliate } \\
\text { Exports }\end{array}$ & $\begin{array}{c}\text { Affiliate } \\
\text { Imports }\end{array}$ & $\begin{array}{c}\text { Affiliate } \\
\text { Exports }\end{array}$ \\
\cline { 2 - 5 } All countries & 14 & 15 & 15 & 10 \\
Canada & 41 & 42 & 14 & 10 \\
France & 5 & 4 & 16 & 13 \\
Germany & 5 & 3 & 15 & 13 \\
Netherlands & 7 & 4 & 13 & 7 \\
Switzerland & 4 & 6 & 8 & 11 \\
UK & 6 & 5 & 9 & 10 \\
Australia & 9 & 4 & 10 & 11 \\
Japan & 12 & 4 & 23 &
\end{tabular}

Source: Markusen (2002) 
Table 2: OLS Regressions using U.S. Affiliate Sales

$\underline{\text { Skill-abundant Home }}$

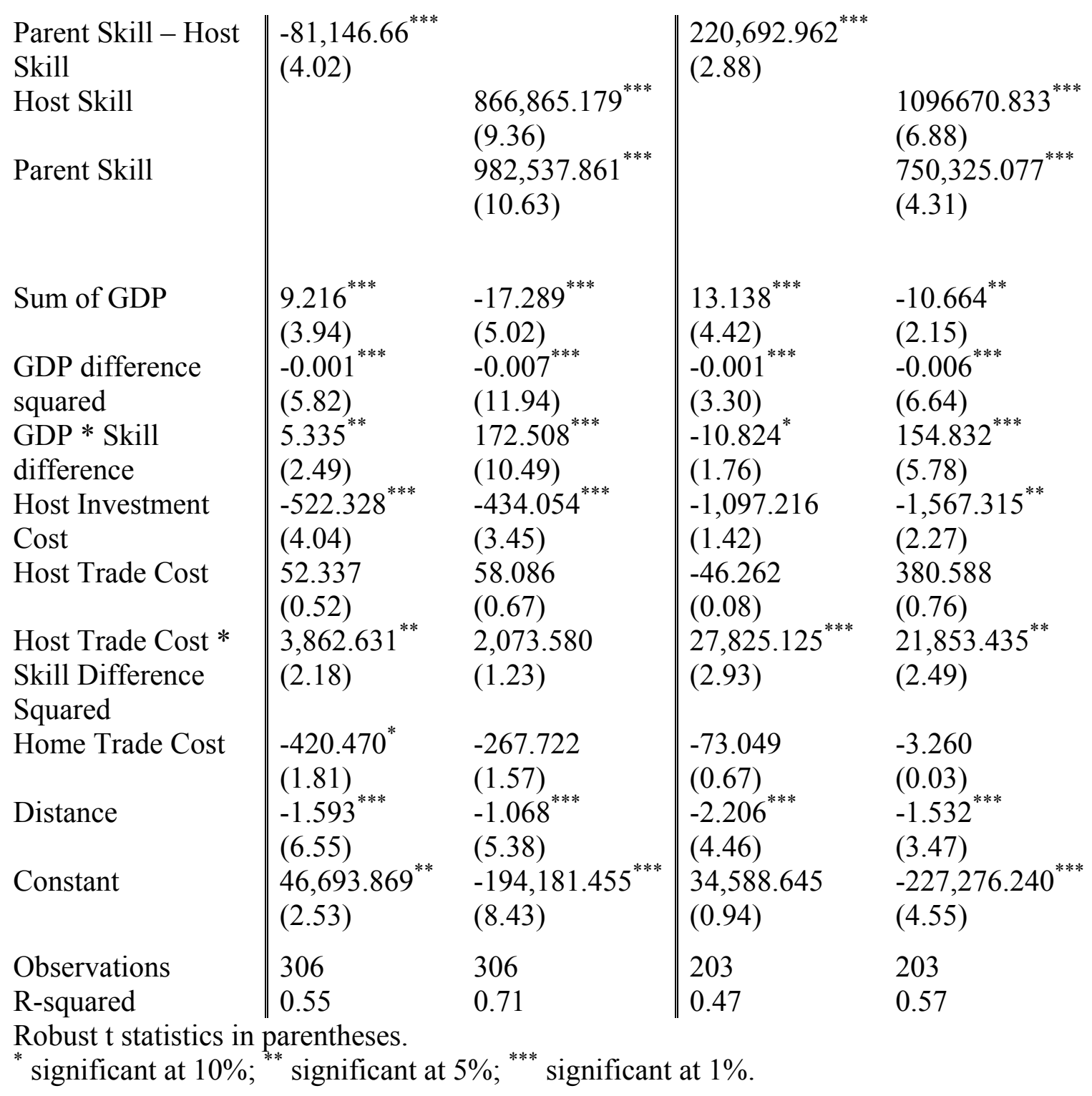

